\title{
Japan-New Business Opportunities in an Established Market
}

PARISSA HAGHIRIAN, RUDOLF R. SINKOVICS, AND VICKY BAMIATZI
The recession during the last decade hit Japan's image as an economic powerhouse hard. It added a layer of skepticism to the already existing difficulties in coping with tariff and nontariff entry barriers as well as cultural and business differences. However, even against the background of strong economic transformations in countries such as India and especially China and a strong enthusiasm for dealing with these upcoming economies, it should not be forgotten that Japan is still the world's second-largest economy in terms of gross domestic product. Japan offers an array of business opportunities for foreign investors. As employment and other traditions are under pressure from a young generation more in tune with Western culture and ideas, the Japanese triad market allows for a promising future. This article aims to inform managers who wish to extend their market reach of the tremendous opportunities in the Japanese market. We unveil cultural particulars and challenges for foreign businesses that allow for a refreshed look into the economic miracle of the second half of the twentieth century. (C) 2008 Wiley Periodicals, Inc.

Japan has always been seen as a very challenging market, yet the picture has looked especially gloomy in the past years. Having experienced an economic crisis for more than a decade, Japan has made many foreign investors skeptical about investing there. However, recent developments point to the direction of the re-emergence of Japan on the top playing field of international competition. More specifically, a strong commitment to gradual reform has been central in the political agenda of the previous and current governments, while economic indicators are also delivering positive results. Furthermore, it should not be forgotten that Japan is not only Asia's economic hub, but still the world's second-largest economy in terms of gross domestic product (GDP). It presents a profitable investment environment with a mature market of 127 million consumers who not only possess the pole position in terms of spending power worldwide, but also demonstrate a willingness to use it. Japanese consumers are engaged in a perennial love affair with technological developments and show strong interest in innovative products. Finally, incremental adjustments are under way in politics, corporate law, capital markets, financial regulation, labor law, and practices and have fundamentally altered incentives guiding society.

It is against the background of this increasingly attractive investment environment that this article aims to give a refreshed look into the economic miracle in the 1980s and the recession of the last decade and the effects it had on the Japanese economy. We address managers who wish to extend their market reach so as to familiarize them with the tremendous opportunities of the Japanese market. We unveil cultural challenges for foreign businesses interested in investing in the Japanese market and also provide a number of practical do's and don'ts on how to negotiate with Japanese business partners.

\section{The Japanese Business Environment}

\section{Economic History}

During the last 50 years, Japan presented a highly volatile economic history. In 1952, after the Allied occupation, Japan became one of the first lessdeveloped countries in the postwar period that managed to graduate to developed-nation status. It had an annual growth rate of $8-10$ percent by 1973 and was one of the largest economic powers in the world by 1985 , presenting a surplus balance of payments amounting to 3.7 percent of the GNP. The rapid 


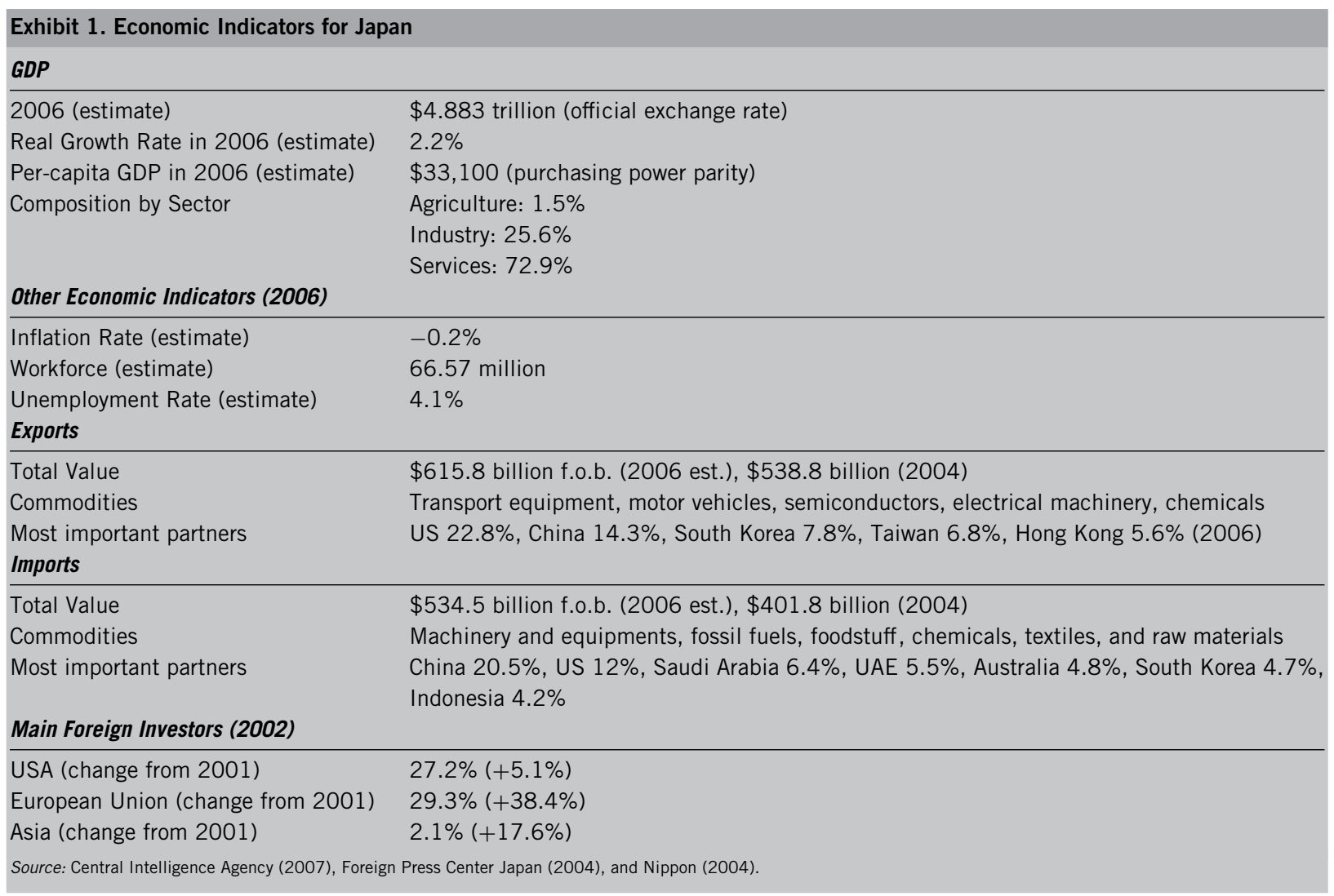

appreciation of the yen in 1985, however, along with the interest rate decrease, the real estate bubble, and the consequent credit crisis, drove the country into a decade of recession. This inevitably forced the Japanese economy into low growth for more than a decade until the year 2000. Only in 2003 did the Japanese economy start to show subtle signs of recovery, while in 2004 its GDP reached an average growth rate of 2.6 percent, presenting a stable positive trend for the future. Exhibit 1 summarizes Japan's economic indicators.

\section{Investing in Japan}

The last decade's investment in Japan has been overshadowed by the attraction of the People's Republic of China. However, while investors in China are challenged by poorly developed infrastructure and legal systems, Japan provides a mature investment environment. Japan scores high on the index of eco- nomic freedom, with a score of $1^{1}$ in monetary policy, and 2 in wages/prices and in property rights and trade policy. Although fiscal burdens are still perceived high (scoring 4.3) and the banking and finance sectors have repeatedly been seen as areas of concern (score of 4; Heritage, 2004), the ongoing and planned fiscal reforms form the basis of a very promising future in these areas. In terms of wealth distribution and GDP, Japan promises an affluent economic climate; even after the burst of the real estate bubble and financial crisis, Japan's household savings were as high as U.S. \$10.3 trillion in 1997. Japan's total GDP still outperforms every other Asian country, accounting for 10.44 percent of the world's GDP. Exhibit 2 compares the GDP and GDP per capita between Japan and its neighbors. On top of this, Japan shows the highest standards in terms of infrastructure and telecommunications in Asia and has a highly educated workforce of 


$\begin{aligned} & \text { Exhibit 2. Comparison of the GDP and GDP Per Capita Between } \\
& \text { Japan and Other Countries in the Region } \\
& \text { GDP (official exchange } \\
& \text { rate) (in billion } \$ \text { ) }\end{aligned}$
\begin{tabular}{lcc} 
Country & GDP per capita $\mathbf{\$}$ ) \\
\hline Japan & $\$ 4,833.0$ & 33,100 \\
China & $\$ 2,527.0$ & 7,800 \\
Korea South & $\$ 897.4$ & 24,500 \\
India & $\$ 805.5$ & 3,800 \\
Taiwan & $\$ 346.7$ & 29,600 \\
Indonesia & $\$ 264.7$ & 3,900 \\
Thailand & $\$ 197.7$ & 9,200 \\
Hong Kong & $\$ 188.8$ & 37,300 \\
Malaysia & $\$ 132.3$ & 12,800 \\
Singapore & $\$ 122.1$ & 31,400 \\
Philippines & $\$ 116.9$ & 5,000 \\
Bahrain & $\$ 12.1$ & 25,600 \\
World & $\$ 46,770$ & 10,200 \\
Source: Central Intelligence Agency (2007).
\end{tabular}

66.57 million people, about 74 percent of whom hold a university or college degree.

Japan's FDI Potential Index, an indicator of the quality of the legal and economic framework that determines investment success, scores at 0.586, which places Japan within the top 20 countries in terms of potential for foreign investment. China, in comparison, is in a much lower position (84).

Investors in Japan report that the business environment is becoming less regulated, more open to foreigners with new products and different ways of doing business. European corporations currently account for the most prominent foreign investors. In 2002, their share of FDI to Japan was 29.3 percent, with the United States following at 27.2 percent, while in 2004 Japan was the second ${ }^{2}$ most important destination country for EU investments ( 8 billion euros). Japan's market is of strategic importance internationally as well as within the Asia-Pacific region. It is the second-largest consumer market in the world, with more than 120 million affluent customers. Furthermore, Japan is the most seasoned market in terms of consumerism in the region, pre- senting a perfect test market before entering other prospective host markets.

Another argument that is highlighted by foreign investors is the low risk factor when conducting business in Japan. Payment behavior of Japanese customers is reported to be very good. Interestingly, foreign investors also consider it advantageous to be perceived as "Gaijin" (non-Japanese) companies. While in the literature foreignness is sometimes seen as a liability that needs to be overcome, it proves a key advantage in the Japanese market. Managers report that it allows them to move more freely in the market and enables differentiation strategies from Japanese competitors. With the majority (99.7\%) of Japanese companies in the small- and mediumsized sector, local competition is largely domestic market-focused, lacking effective strategies of international competition. Foreign companies showing a high degree of differentiation often manage to turn this market trend to their own advantage. Finally, investments in Japan appear to bear fruit fairly quickly. In a survey conducted by the German chamber of commerce, about 47 percent of the companies reported a break-even period of less than four years. Only about 4 percent of companies reported a break-even period of ten years for their investments.

\section{Recent Changes}

The main reservation of investors interested in the Japanese market is based on the slow economic growth over the last decade. However, the recession has also caused a number of traditionally rigid structures to break down and opened up investment opportunities for foreign investors. Typical Japanese management practices, such as lifetime employment and the seniority system, are increasingly being challenged, and there is a trend toward American-style management practices, with far-reaching implications regarding the traditionally tight connections between companies (keiretsu) that are still considered to be too dominant in terms of distribution. A widely discussed example in this context is Renault's 
investment in Nissan Motors in 1999. Nissan, a very traditional Japanese car manufacturer, was suddenly faced with a foreign CEO, and tremendous restructuring efforts, such as the layoff of 21,000 employees and the introduction of a merit-based compensation system. CEO Carlos Ghosn even managed to disentangle the company from its historical keiretsu relationships, thus facilitating a company turnaround within four years, and creating a symbolic case for necessary as well as possible changes to the Japanese economy.

Japan's traditional retail system was also challenged due to the recession. Unsettled by the economic events, Japanese consumers-traditionally equating price and quality and sticking to high-price Japanese brands-developed more cost-consciousness and welcomed changes in the distribution environment, such as discount stores and hypermarkets. After 1995, a number of Western retailers entered the Japanese market and presented new distribution systems like convenience stores, discount outlets, and mail order shopping.

\section{Governmental initiatives increased the accessibility} of the Japanese market, particularly for producers of high-quality goods where local market presence is the key dimension in generating important market knowledge and developing closeness to customers.

The recession also left its mark on labor and rent costs, which witnessed an ongoing downward trend over the last five years. While until recently, Japan was not necessarily considered by company managers looking for cheap manufacturing capabilities, there are strong arguments that this view might be changing. Governmental initiatives increased the accessibility of the Japanese market, particularly for producers of high-quality goods where local market presence is the key dimension in generating important market knowledge and developing closeness to customers.
Last but not least, recognizing a need for improvement, the Japanese government has promoted foreign investment in Japan and inaugurated the "Invest Japan" campaign by establishing offices at each ministry, agency, and institution concerned with international business to provide necessary information for potential foreign investors. The previous prime minister, Junichiro Koizumi, unequivocally welcomed foreign direct investments as a way to revive the country's economy; while following his path, the new prime minister, Yasuo Fukuda, also promotes structural reformation but with caution about the inequalities that may arise during that process.

\section{Barriers to Investing in the Japanese Market}

Japan has been secluded from foreign markets for many years. This was originally initiated by the third shogun lemitsu, who-in an attempt to create internal peace and stability-expelled all foreigners and sealed off the country from the rest of the world for about 200 years until 1853 . This period therefore became significant for the development of unique social and business practices-the legacy of which remains a strong pillar in Japanese modern life and business today. Many aspects of Japanese management and negotiation practices are still rooted in traditional concepts of interaction and communication, which pose barriers to communication with Western business partners.

\section{Hierarchy}

The roles of Japanese individuals in everyday life are well defined. In Japan, most relationships are based on vertical or superior-subordinate relationship. All individuals are ranked within their respective organizations. The higher the rank/status of their employer, the higher they are perceived in the hierarchy. Japanese will usually respect those with a higher rank and interactions between members of different ranks follow clear guidelines. Accordingly, Japanese are often confused when confronted with foreigners who do not clearly indicate their rank right away. 
Partners in business negotiations need to be of a similar rank. Sending specialists of lower rank than their counterpart can be considered very rude and pose detrimental effects to negotiation outcomes.

Relationships between buyers and sellers are also hierarchical. Generally, customers hold all the power, which explains the strong focus of Japanese companies on meeting customer expectations. Japanese companies demonstrate a perennial desire for the development of innovative products and engage in high levels of after-sales service. These specific aspects bear fundamental challenges for foreign investors.

\section{Japanese companies demonstrate a perennial de-} sire for the development of innovative products and engage in high levels of after-sales service.

\section{Group Orientation}

Belonging to a group is very important for the Japanese and is accompanied by a plethora of duties. Great importance is placed on interpersonal harmony, social interaction, and relationships. As you would expect, this endeavor for harmony ties individuals to norms and rules and restricts them from "sticking out." As a consequence, a high degree of self-restraint can be witnessed, which makes Japanese unlikely to express disagreement with majority opinions. Since no person alone has the authority to make decisions on an individual basis, Japanese decision making displays many democratic elements. Many parties are involved in the decisionmaking processes, and there is a sincere pursuit of high acceptance for future interactions. Naturally, this approach consumes enormous amounts of management time and is-measured by Western standards—often considered to be dysfunctional.

\section{Risk Avoidance}

The Japanese culture displays a tendency to avoid risk. Responsibilities are shared with other mem- bers of the group, team, or corporation. Formally, the procedure of reaching a conclusion employs an instrument called ringi seido (ringi system). A ringisho (ringi document) is a written proposal that is circulated throughout various departments and then up along the management chain. Normally, an employee will prepare a proposal or report, and each colleague and senior person will add a comment and stamp his approval. If approval is not reached, the proposal will be changed or rejected. This is a very time-consuming process but provides a strong foundation for sharing responsibility with other members of the corporation and reaching an overall consensus within the workforce. Risk avoidance also leads to high degrees of discipline, which is evident to even cursory visitors to Japan. In terms of business relationships, it is important to realize that overly careful planning is necessary to prepare negotiations and meetings between potential partners.

\section{Communication Style}

Politeness in any type of conversation is crucial when negotiating with Japanese business partners. Japanese etiquette requires proper use of language levels at every occasion. Before talking to unknown parties, Japanese need to find out about their rank or status to ensure the appropriate way of communication.

\section{Personal and Public Opinion}

Japanese differentiate between public and private life, and also between their "public" (tatemae) and "private" (bonne) opinion. The latter represents one's true feelings, which may not always be expressed in public contexts. Honne and tatemae are present in all contexts of modern Japanese life and are probably the two most difficult concepts for Westerners to understand, leading them often to perceive Japanese communication styles as vague. Practically, a suitable approach to tackle the communication difficulties with Japanese is to ask many polite and indirect questions. This can help develop a better sense of one's counterpart's true opinion. 


\begin{tabular}{|c|c|}
\hline \multicolumn{2}{|c|}{$\begin{array}{l}\text { Exhibit 3. Contact Information-Trade Association and } \\
\text { Chambers }\end{array}$} \\
\hline Trade Associations & \\
\hline $\begin{array}{l}\text { JETRO (Japan External Trade } \\
\text { Organization) } \\
\text { Japan Foreign Trade Council } \\
\text { Federation of Economic Organizations } \\
\text { (Keidanren) } \\
\text { Chambers of Commerce }\end{array}$ & $\begin{array}{c}\text { www.jetro.go.jp } \\
\text { www.investjapan.org } \\
\text { www.jftc.or.jp } \\
\text { www.keidanren.or.jp }\end{array}$ \\
\hline $\begin{array}{l}\text { American Chamber of Commerce } \\
\text { Canadian Chamber of Commerce } \\
\text { European Business Council in Japan }\end{array}$ & $\begin{array}{l}\text { www.accj.or.jp } \\
\text { www.cccj.or.jp } \\
\text { www.ebc-jp.com }\end{array}$ \\
\hline
\end{tabular}

\section{Overcoming the Barriers: Entering} the Japanese Market

Companies entering the Japanese market usually follow a typical infiltration pattern.

\section{Finding Japanese Business Partners}

Since foreign investors often find it very difficult to overcome nontariff barriers of entry, they usually start their initial activities in the Japanese market through local importers. Japanese are avid collectors of information. Market and industry information is available in English and can be found via the Japanese trade associations and the chambers of commerce Web sites, as shown in Exhibit 3. These institutions offer support in finding local partners, importers, or trading companies and help access the Japanese market.

The name and reputation of one's company as well as one's partner is highly important in Japan. Influential business partners can substantially ease the market entry process, open many doors, and facilitate negotiation processes. However, the identification of potential business partners requires patience. Most foreign companies report that it may take up to six or nine months to find appropriate business partners. Generally, potential Japanese partners are very meticulous in accumulating detailed information including company history, business engagements outside the Japanese market, and company reputation. The diligence with which Japanese corporations pursue the process can be very irritating for foreign investors who lack Japan-specific experience, which is why investors often report this phase of market entry to be the most challenging one.

\section{The First Five Years}

Once a partnership is established, the Japanese partner starts promoting the new products/services through his existing customers, resulting in smoother and faster market penetration, product awareness, and stable customer base development. However, it has been reported that after a five-year period, on average, business ventures collapse and foreign investors find it more appropriate to set up their own managed subsidiaries. Some of the most common reported reasons appear to be the cultural differences in terms of customer relations, the difference in risk tolerance, and the different attitudes in product management practices between the Japanese partner and the Western headquarters. The possibility of terminating partnerships after a certain time should therefore be clearly stated in the initial relational agreement.

\section{The Japanese Subsidiary Manager}

Many investors are faced with the dilemma of having to decide in favor of Japanese or Western subsidiary managers. Often, expatriates are preferred, which allows the establishment of higher levels of formal and informal control between headquarter and subsidiaries, reduces the federative nature of the relationship, and improves interorganizational communication. However, when dealing with traditional industries (e.g., construction) or small and medium-sized enterprises, the appointment of Japanese subsidiary managers with industry background, network relationships, and an understanding of Japanese idiosyncrasies may be more appropriate. Many business partners in these industries do not speak English and feel intimidated in negotiations with non-Japanese counterparts, and so, to overcome this, local business knowledge may prove helpful. 
Interestingly, in nontraditional industries or when cooperating with business partners in Tokyo, foreign managers have become commonplace and indeed very successful. Non-Japanese managers sometimes enjoy the freedom to act outside culturally predetermined expectations and may enforce unpopular activities. Foreign female managers report little hindrance when working in Japan. Since business in Japan is dominated by men, whatever industry is concerned, foreign women stand out and often find it easier to talk to customers and establish relationships with clients or other industry members.

\section{Market Establishment}

Doing business in Japan requires commitment to adapt to Japanese standards, especially to Japanese expectations toward quality and service. In Japan quality permeates every aspect of a product and involves continuous attention to improvement. New market entries in Japan are often based on technology, and foreign companies are confronted with high expectations, requirements, and customer demand, as Japanese consumers generally assume that the quality of Japanese products is superior to Western ones. Japanese consumers and customers also expect more information about products and the company, which is why many investors provide a great amount of information about the company itself in the form of detailed Japanese pamphlets.

\section{Doing business in Japan requires commitment to adapt to Japanese standards, especially to Japanese expectations toward quality and service.}

\section{Marketing Issues}

Product and service adaptations are not only costly, but also resource- and time-consuming, presenting a continuous challenge for many investors. Moreover, standardized marketing-mix practices (based on scale and scope efficiency rules) usually contradict the adaptation practices followed by local rep- resentatives, which create conflicts between headquarters and subsidiaries. Another important aspect when selling consumer products is packaging, as the packaging of products shows courtesy and respect. Most producers are required to develop custom packages and wrappings to meet Japanese consumer tastes.

\section{HR Issues}

Access to experienced staff may also be difficult. Western companies tapping into Japan often face problems identifying qualified staff. Japanese companies traditionally hire employees directly after their graduation and provide life-long employment, a seniority promotion system, and an array of "typical” Japanese fringe benefits (e.g., bonus payment). While this perspective is increasingly challenged by Western-style management systems and human-resource practices, and lifetime employment and commitment have recently been reinterpreted, emotional ties with Japanese companies are still very high. Up to the mid-1990s Japanese employees rarely changed jobs during their careers; working for a foreign company was considered risky and a return to a "traditional" Japanese company largely impossible. However, increasing unemployment has led to higher flexibility on the labor market and changed employees' attitudes toward careers in foreign enterprises. Being hired by a Japanese company is no longer seen as a ticket for lifetime employment. Foreign corporations also report that an increasing number of career-oriented women are applying for employment in foreign enterprises. These businesses offer Western-style careers and more job responsibility, and working conditions and benefits in foreign affiliate corporations are increasingly appreciated by Japanese employees.

\section{Japanese Business Etiquette}

Awareness or cursory knowledge of Japanese business etiquette is considered a necessary ingredient of successful negotiation outcomes in Japan. There are four main dimensions of business etiquette: exchanging business cards, business meetings, giving 
gifts, and relationships after work. Name/business cards are mostly used to communicate the hierarchical status of the name card giver. Since human interaction is strongly influenced by the position of the communicators, cards convey important information, and so it is advisable to bring name cards in Japanese, especially when planning long-term business there.

Japanese business meetings generally convey different meanings than Western business meetings. Their main purpose is to meet and inform participants involved, as well as to create some common understanding about the topic. Every aspect of the topic needs to be discussed, sometimes two or more times. Meetings in Japan therefore usually take much longer than in the West. Decisions are not usually made during a business meeting. Western negotiators should therefore not expect to come up with a contract or a sales order by the end of a first business meeting, but try to make their point clear. If possible, problems or sensitive topics are preferably solved beforehand, in a process called nemawashii. This describes a communication technique to avoid conflicts and achieve consensus in decision making. Nemawashii is usually conducted through preliminary meetings and confidential one-to-one consultations and is supposed to prevent surprises.

\section{Japanese prefer large negotiation teams, because} they require wider participation within their corporations to take decisions.

Japanese prefer large negotiation teams, because they require wider participation within their corporations to take decisions. They also need to feel comfortable with their business partners. Hence, meetings mostly start with the exchange of nontask-related information and a brief introduction of all participants. Most negotiations will most likely be conducted by middle managers. Since Japanese are very rank-conscious, their Western counterparts should be of the same rank. Furthermore, as in most Asian countries, age is synonymous with wisdom and experience, so that it is advisable to meet Japanese business partners with older colleagues, even if they are not allowed to make decisions. During the negotiations, it is very important to distinguish and address the senior decision makers on the Japanese side. In many cases, they will be the oldest members of the team and do not speak English. Younger members are very likely to speak better English but have little influence. The number of Japanese business officials who speak English fluently is limited. Most Japanese learn English for many years in high school but are often reluctant to use this knowledge with foreigners. Nevertheless, written material on topics of negotiation and/or business management is very helpful. An interpreter is, in any case, advisable.

Japanese give gifts out of a sense of obligation, but also to convey feelings of gratitude or regret. There are specific guidelines for types, prices, and packaging of gifts. Due to the hierarchical structure of the Japanese society, brand, price, and packaging of presents must accord with the status of both the giver and the recipient.

Socializing and going out after work is customary for Japanese businessmen and usually obligatory for foreign partners. Business-related activities and events are usually carefully organized dinners in restaurants. Business dinners last about two or three hours and may start as early as 6:30 p.m. They offer good opportunities for networking, because they allow the establishment of more personal relationships between all participants, and allow informal communication with superiors or customers.

Finally, Exhibit 4 details some additional rules of etiquette that are important to ensuring smooth business relationships in Japan. 


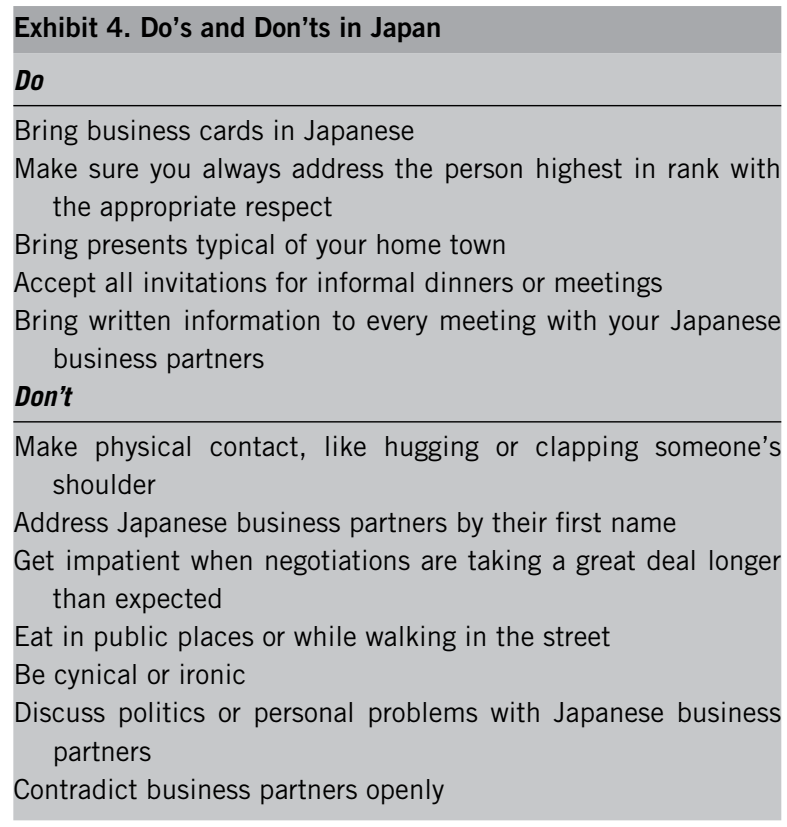

\section{Conclusion}

Despite Japan's recent economic recession, the country still offers an array of business opportunities for foreign investors. This article points at opportunities in terms of investment decisions and market entry, which the world's second-largest market offers to foreign investors.

Two main aspects have to be acknowledged when trying to enter the Japanese market. First, business with the Japanese is largely based on interpersonal relationships. Japanese business partners develop relationships over a long period of time and engage in trusting partnerships. Developing business relationships thus requires a lot of patience, meetings, and energy-consuming socializing activities such as dinners. Short "transactional" visits or contacts established at trade fairs will not suffice to the building of long-lasting profitable business relationships. Time spent with customers is vital, as the more time spent with a potential client, the more interest and commitment is demonstrated.

The second crucial aspect when doing business with the Japanese is a high degree of adaptation to Japanese consumers' expectations. Japan is one of the most sophisticated markets worldwide and cannot be compared with any other Asian market. Japanese consumers are used to high levels of service delivery and product quality, while their tastes and expectations often differ substantially from Western ideas. It is therefore rarely possible to transfer Western marketing concepts to Japan. This may be one of the biggest obstacles when entering the Japanese market, and for that many companies, despite having been successful in other parts of the world, have stumbled badly in Japan.

Finally, an understanding of Japanese culture, society, and business etiquette is necessary for doing business in Japan.

\section{Notes}

1. Index ranges from $1=$ excellent to $5=$ poor.

2. The first was China with 9 billion euros.

\section{References}

Central Intelligence Agency. (2007). The world factbookJapan [Online]. Retrieved December 9, 2007, from http:// www.odci.gov/cia/publications/factbook/geos/ja.html

Foreign Press Center Japan (FPCJ). (2004). Facts and figures of Japan 2004. Retrieved October 25, 2007, from http://www.fpcj.jp/e

Heritage. (2004). Japan-2004 index of economic freedom. The Heritage Foundation. Retrieved November 15, 2004, from http://www.heritage.org/research/features/index/ countryFiles/English/individual_pdfs/Japan.pdf

Nippon. (2004). Nippon information [Online]. Available at http://www.nippon.com/

\section{Additional Resources}

Abegglen, J. C. (2006). 21st century Japanese management: New systems, lasting values. Houndmills and Basingstoke, UK: Palgrave Macmillan.

Abegglen, J. C., \& Stalk, G. Jr. (1985). Kaisha, the Japanese corporation. Tokyo: Charles E. Tuttle Company. 
American Chamber of Commerce in Japan (ACCJ). (2004). The long road to reform. Retrieved November 15, 2004, from http://www.accj.or.jp/tmp/longroadE.pdf

Berger, R. (2005). Making money in Japan: A profitability survey among German affiliates in Japan. Tokyo: Roland Berger Strategy Consultants \& Deutsche Industrie- und Handelskammer in Japan.

Chen, M. (2004). Asian management systems. London: Thomson.

De Mente, B. (1994). Japanese etiquette \& ethics in business. Chicago: NTC Business Books.

Dunung, S. P. (1998). Doing business in Asia: The complete guide. San Francisco, CA: Jossey-Bass.

Fields, G., Katahira, H., \& Wind, J. (2000). Leveraging Japan: Marketing for the new Asia. San Francisco, CA: Jossey-Bass.

Gakken. (2002). Japan as it is. Tokyo: Gakken.

Gauthier-Villars, D. (2000). What makes Carlos Ghosn tick? Far Eastern Economic Review, 163(37), 64.

Ghosn, C. (2002). Saving the business without losing the company. Harvard Business Review, 80(1), 37-45.

Going hybrid: A special report on business in Japan. (2007). The Economist, pp. 3-17.

Government of Japan. (2005). Annual report on the Japanese economy and public finance. Tokyo: Government of Japan, Cabinet Office.

Haghirian, P. (2006). Research report-Market entry of Austrian SMEs into Japan (in German: Martkeintritte österreichischer Klein- und Mittelbetriebe in Den Japanischen Markt). Wien: Julius-Raab Stiftung.

Japan dispatches the Sdf to Iraq. (2004). Japan Echo, 31(1). http://www.japanecho.com/sum/2004/310106.html.

Jeong, D. Y., \& Aguilera, R. V. (2008). The evolution of enterprise unionism in Japan: A socio-political perspective. British Journal of Industrial Relations, 46(1), 98-132.

Jetro. (2003). 2003 Jetro White Paper on International Trade and Foreign Direct Investment. Jetro Japan. Retrieved October 25, 2004, from http://www.jetro.go.jp/it/e/pub/ whitepaper/2003.pdf

Kodansha. (2003). Bairingaru Nihon Jiten. Tokyo: Kodansha International.

Lasserre, P., \& Schuette, H. (1999). Strategies of Asia Pacific, beyond the crisis (Revised and updated paperback edition). Houndmills, UK: Macmillan.
Maguire, K. (2001). Penetrating the Japanese market: The challenge of non-tariff barriers. European Business Review, 13, 241-249.

Melville, I. (2000). Marketing in Japan. Oxford, UK: Butterworth-Heinemann.

Ojala, A., \& Tyrväinen, P. (2008). Best practices in the Japanese software market. Global Business and Organizational Excellence, 27(2), 52-64.

Sako, M. (2008). 21st century Japanese management: New systems, lasting values-by James C. Abegglen. British Journal of Industrial Relations, 46(1), 200-201.

Samiee, S., \& Mayo, A. (1990). Barriers to trade with Japan: A socio-cultural perspective. European Journal of Marketing, 24(12), 48-66.

Schuette, H., \& Ciarlante, D. (1998). Consumer behavior in Asia (1st ed.). London: Macmillan.

Shinomiya, S., \& Szepkouski, B. (2002). Business passport to Japan. Tokyo: ICG Muse.

Special report: Investing in Japan. (2005, March 30). Financial Times, p. 1.

(Still) made in Japan. (2004, April 10). The Economist, p. 94. The sun also rises-A survey of Japan. (2005, October 8). The Economist, pp. 3-18.

Tokoro, M. (2005). The shift towards American-style human resource management systems and the transformation of workers' attitudes at Japanese firms. Asian Business \& Management, 4(1), 23-44.

Yamin, M., \& Forsgren, M. (2006). Hymer's analysis of the multinational organization: Power Retention and the demise of the federative MNE. International Business Review, 15(2), 166-179.

Zaheer, S. (1995). Overcoming the liability of foreignness. Academy of Management Journal, 38, 341-361.

Parissa Haghirian is an assistant professor in the Faculty of Liberal Arts at Sophia University in Tokyo, Japan. Her research focuses on Asian management, market entry into Japan, and cultural differences in dealing with Japanese management. She received her PhD from the Vienna University of Economics and Business Administration, Austria, and has taught at other universities in Japan and Western Europe.

Rudolf R. Sinkovics is a senior lecturer in international business at the University of Manchester, Manchester Business School, United Kingdom. His research centers on interorganizational governance, the role of ICT in firm 
internationalization, and research methods in international business. He received his PhD from the Vienna University of Economics and Business Administration, Austria.

Vicky Bamiatzi is a doctoral student in international business and strategy at the University of Manchester, Manchester Business School, United Kingdom. Her research focuses on the managerial, human, social, and strategic factors that drive superior performance in declining industries in the United Kingdom. She holds a BSc. degree in business administration as well as an MSc. in decision sciences/financial engineering from the Athens University of Economics and Business (AUEB), Athens, Greece. 